\title{
Ecotourism Among Dilemma Voluntarism and Ecological Commitment (A Review of the Challenges of Community-Based Environmental Tourism Development in Bangka Island)
}

\author{
Ibrahim Ibrahim $^{1}$, Nizwan Zukhri ${ }^{2}$, Rendy Rendy ${ }^{3}$ \\ $\left\{\right.$ iim_babel@yahoo.com ${ }^{1}$, nizwan_ubb@yahoo.com ${ }^{2}$, rendy@ugm.ac.id $\left.{ }^{3}\right\}$ \\ Bangka Belitung University, Indonesia ${ }^{1}$ \\ Bangka Belitung University, Indonesia ${ }^{2}$ \\ Bangka Belitung University, Indonesia ${ }^{3}$
}

\begin{abstract}
Bangka is well known as a region which is rich of natural resources, mainly in tin commodity. Tin mining has been done for hundreds of years and has left massive environmental damage in this region. As the growth of community's collective awareness towards the threat in the future, the desire to improve the environment while taking economic benefit from the process which appears at several points. Ecotourism has developed in several regions on this island. Interestingly, some of the ecotourism's are community based. However, there are still various challenges arise along with the emergence of new obstacles. This paper examines how the challenges in developing environmental tourism on Bangka Island. The study used in this paper was qualitative study which used three data collection techniques, namely observation, interview, and documentation. This study was chosen with the consideration that it could explore in more detail and depth about the ecotourism management. The chosen locations are new and popular tourist areas with environmental nuances which are connected with the mining area and around the mining area as the main object. This study found several interesting things. First, the ecotourism management was faced with the challenges of developing collective spirit among the initiators. The dilemma between voluntarism which was based on volunteering and economic interest oriented on the income became a big challenge. Second, the ecological rescue commitment is in fact more dominant as the consideration than the economic impact. This study proved that community-based environmental could still develop well. Third, the government always comes later to accompany the initiation of the community. Furthermore, the government should fully present and help along with the commitment to empower the community and should not always be profit-oriented and privatized.
\end{abstract}

Keywords: Ecotourism, Voluntarism, Ecology, Environmental Tourism, Bangka.

\section{Introduction}

Bangka Island is an archipelago which is located in the southern region of Sumatra Island. As an archipelago, Bangka is well known as a region with a beautiful and charming stretch of coastline. Furthermore, this region is also known as a region of tin mining and as white pepper 
producer. In the context of tin mining, Bangka's topography has changed and damaged because of the results of the mining [1]. Data from the Central Bureau Statistics of the Province of Bangka Belitung Island [2] showed that the tin mining was the second economic sector that supported the economy of the people in this region after the plantation sector. In addition, Ibrahim, et al [3] showed that economically, Bangka Belitung was still dependent on the tin economy. Therefore, it is indicated that the existence of the tin mining is still very important.

Along with the occurrence of tin mining which has been done continuously by the people and companies, both in small and large scale, then the environmental damage and landscape changes are inevitable. At the same time, the tin mining has shifted to the sea area and began to cause new problems for small islands and coastal areas [4] [5]. Moreover, not a few coastal areas are damaged by offshore tin mining. In the plantation sector, Bangka which is originally known as a white pepper producer, began to decrease along with the shifting of livelihoods of the people from the plantation sector to the mining sector.

Indeed, the tin mining has begun to be massive since the enactment of regional autonomy which has given authority about certain systematization of regulation to the local government. The gap of tin regulation which at the beginning of the reform was not regulated by the central government caused at least since 1998, the tin mining was done excessively in this area [6]. The term 'people's mining' emerged, which was originally only operated by large company. After running for about 20 years, the awareness of the importance of preventing environmental damage from the tin mining began to emerge. Since the last few years, the ecological rescue movement had developed among the citizens, both collectively and individually. The rescue movement was then transformed into ecotourism when a locus changed and managed as a tourist area. Ecotourism itself is often understood as sustainable tourism [7] which has become a new trend as a nature lover community [8], [9], although [10] the difference is laid on sustainability aspect.

This paper examined three different locations, namely the management of Kolong Biru in Nibung village, Central Bangka; Mangrove Tourism Area in West Kurau, Central Bangka Regency; and Rabeng Perpat Permai Belinyu Tourism Area in Bangka Regency. These three regions were initiated from community-based environmental management and also initiated from the context of management affected by the tin mining. An interesting question that would be focused on this paper is how is the challenge in managing ecotourism in the three regions? This study is initiated from the assumption that there is a problem regarding the main motive of ecotourism management, is the basis of voluntarism or is the basis of economic interests? Then where is the state's position in this context?

\section{Research Method}

This research belongs to qualitative research with an exploratory approach. The researcher focused on the main topic regarding the challenges of ecotourism management on Bangka Island by taking three research loci, namely Kolong Biru Tourism Area in Nibung Village, Central Bangka Regency; Mangrove Management Area in West Kurau, Central Bangka Regency; and Management Area of Rabeng Perpat Permai Belinyu in Bangka Regency. This research also traced the position of manager and government in the ecological dimension and its relationship with economic interests. The data collection techniques used in this study, namely observation, interview, and documentation. Determination of informant was determined based on Purposive Sampling technique, namely the determination of informant based on certain consideration and the belief that the informant had the information needed. In this case, the criteria were the 
initiators and the activists of the management of tourism area, the elements of government around the tourism area, and the visitors.

\section{Discussion}

\subsection{General description of the region}

Basically, there are several areas of community-based environmental tourism management in Bangka Island. However, the three selected regions represent a number of new environmental tourism areas which are currently popular. These three regions are quite visited by the tourists, both from domestic and foreign.

Kolong Biru Tourism Area is located in Nibung Village, includes in the administration of Koba Subdistrict, Central Bangka Regency. This area is located approximately $75 \mathrm{KM}$ from the downtown that is Pangkal Pinang. This tourism area is called as Kolong Biru because in this tourism area there is a large pit under which the water is very blue. This lake is often referred to as Kolong Danau Kaolin. The pit is a whole formed by the result of tin mining. The former tin excavation will move the soil on the surface to take the tin in it, then the former excavation will be flooded and form a pool area which is called as pit. The diameter of this Kolong Biru is approximately $100 \mathrm{M}$ with a depth of approximately $25 \mathrm{M}$.

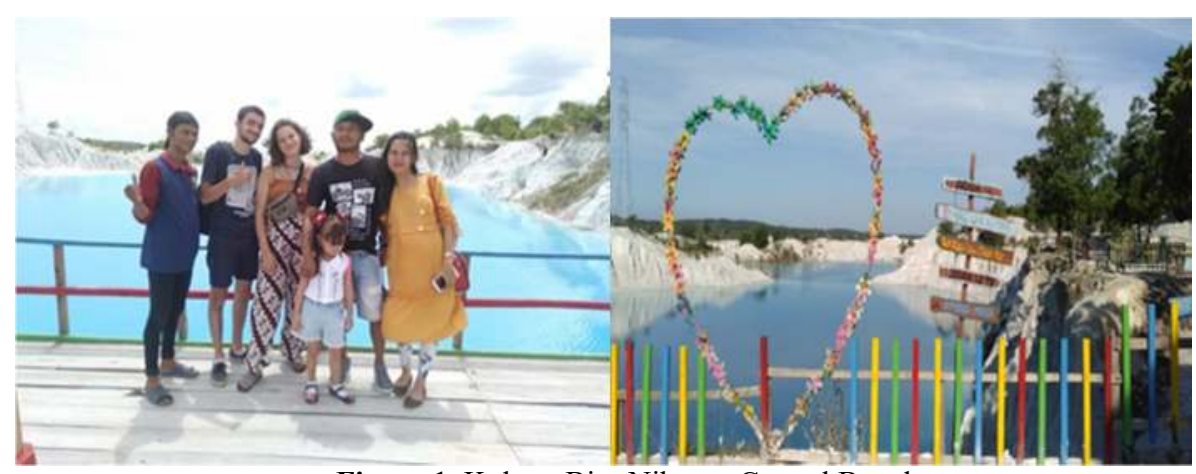

Figure 1. Kolong Biru Nibung, Central Bangka

Kolong Biru Lake has only been popular since 2015 along with the popular use of social media that reported the beauty of this lake. The tourists were from various regions, both domestic and foreign. This pit itself was purely formed from the tin mining process done by PT. Kobatin, a private tin mining company which was no longer in operation. As a former tin mining area, the texture of this area tends to wavy on the mound around the pit and produces interesting spots for photography. This tourism area is well known and viral because this area shows a view of a natural giant pool that is rarely found in other areas. However, legally this area is still included in the administration of PT. Kobatin. Ironically, as a tin mining area, not far from the location of Kolong Biru there is still ongoing tin mining. 


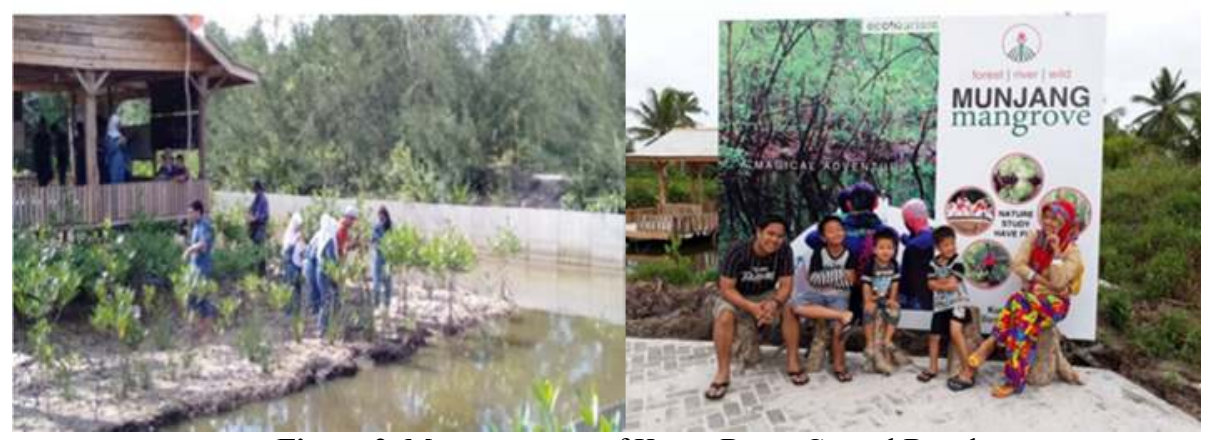

Figure 2. Mangrove area of Kurau Barat, Central Bangka

The next research locus is Rabeng Perpat Permai tourism area, which is located in the Rabeng area, Belinyu Subdistrict, Bangka Regency. Rabeng itself in the language of the local people means mangrove (mangrove forest) which is a mainstay of this tourism area. The location of this tourism area is around $80 \mathrm{KM}$ from the downtown that is Pangkal Pinang and can be reached by land trip for about 90 minutes. This area is located in the coastal area and is one of the new tourism areas which has been developed by local residents. Interestingly, this area combines mangrove crab fisheries in the form of aquaculture and mangrove conservation. This area is located in the coastal area and is connected by a small river to the sea. The manager of this area has provided a tour package along the river and mangrove to the surrounding islands.

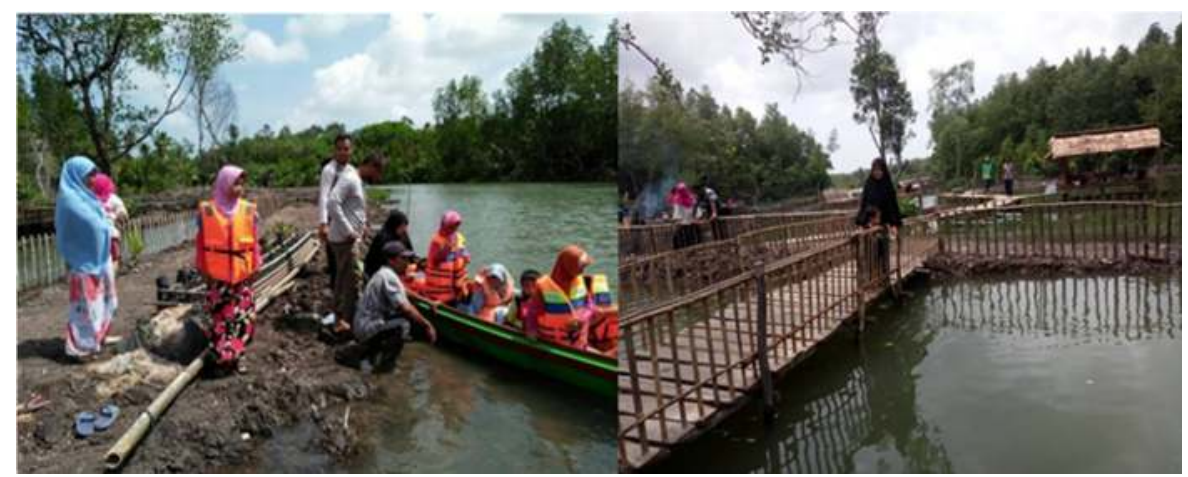

Figure 3. The Area of Rabeng Perpat Permai Belinyu Bangka

This tourism area is managed in a self-help manner and generates income for the people who manage this area. The manager itself is Perpat Permai community which legally established in January 2018, while the land itself is still in the process of the license of management officially. This tourism area provides spots which can be used as a relaxing place for the family. Fishery products are also sold to be served to the tourists who visit in this area. In addition, this area is also used as a coastal conservation area that has an educational function for the residents and young people. 


\subsection{The Voluntarism Dilemma}

The management of Kolong Biru tourism area actually was initiated by personal initiator. It was Darwin who spent a lot of his time to encourage the development of this area. According to Darwin, this area was a hidden location because there were still many tin mining activities around the area, and it was not supported by adequate road access. The residents who passed this area were the residents who went to the garden or went to mining locations. Therefore, Darwin take the initiative to start selling and providing motorcycle taxi service to reach the area. Furthermore, along with the development of the popularity of the area, the support from young people who joined Karang Taruna of Nibung Village began to emerge. This Karang Taruna then expanded the promotion and began to arrange this area to be worth visiting. Zuni, a manager said that the pioneer of this area was Karang Taruna of Nibung Village and thus made this are more widely known. "These people are those who actively promote this area through various social media. They are also diligent in communicating with external parties to get the support ", said Zuni.

While in terms of income, the existence of Kolong Biru has not been able to boost the income of the residents and the managers. The income from parking and sales is only around IDR 8 million per year for the village. Nevertheless, the manager believes that a better future development will give positive impact in the future.

The same condition occurs in the management area of Kurau Barat Mangrove area. The initiator of this area is Yasir and his friends who together build a community called GEMPA 01, namely Young Generations Who Love the Nature. The results of interview with Edo, one of the managers of this area confirms that at first their capital is from self-help and they try to save the Kurau Barat mangrove area which has been affected by tin mining from the seacoast on the surrounding coast. The initial management is carried out by planting mangrove trees using donations from the members, which initially as many as 15 people. There is concern about the impact of tin mining from other affected coastal areas in this area, as well as tin mining in the upstream. This initiation is purely due to the anxiety to utilize available resources positively. Instead of intending to make a big profit, self-help then becomes the key word.

At First, it was unthinkable that the activities they carried out with GEMPA 01 community would bring an adequate income. The self-help organization that was initially held was difficult to be run because of the limited support of resources from various parties. According to Yasir "the support comes after the area is known by many parties, previously it is self-supporting from all friends here", said Yasir. After it has been run since 2017, the visitors are very interested, some of them even visited this area for 5 times, such as one of the visitors named Subhan met by the researcher in this tourism area.

The same thing was also obtained from the management of Rabeng Perpat Permai Belinyu, which from the beginning relied on funds from the self-help to develop this area. Initially, this area was utilized as land for fish farming by a group of local people. From what was originally just a fishpond, this group of local people who called themselves as Perpat Permai Belinyu Association then developed this area into a tourism area. This group was assisted by one of the fisheries lecturers from the local tertiary institution, the fishpond which was originally just one then increased. Besides fish, the manager also cultivated mangrove crabs which were then sold to the visitors who want to enjoy them while relaxing their self in this tourism area. After all, self-help principle remained as a key word because the support came from the visitors had not been adequate, while funding from the government was also limited, at least the income received by this group was approximately 2 million rupiah and then used as the funds to develop this area, not for the self-income purposes. 
Furthermore, besides the managers, there were also many other residents who joined with the manager of this area with enthusiasm to improve the performance of visitors' satisfaction. However, the principle of environmental protection becomes the initial initiation and continues to be a principal challenge for this group because it is not easy to deny the fact that the needs for income to the family economy of the managers. Eva, one of the lecturers who helped in managing the aquaculture of this group, said that the spirit of community volunteerism actually came on a massive scale since this area became popular. "Many residents who are involved and give donations come from outside the original management group. The spirit of helping and volunteering from the residents is very high," said Eva.

The following table is the income of ecotourism management area at the research locus:

Table 1. The Income of ecotourism management

\begin{tabular}{|c|c|c|c|}
\hline Management & Kolong Biru & $\begin{array}{ll}\text { Kurau } & \text { Barat } \\
\text { Mangrove } & \end{array}$ & $\begin{array}{l}\text { Rabeng Perpat } \\
\text { Permai }\end{array}$ \\
\hline Manager & Karang Taruna & GEMPA & $\begin{array}{ll}\text { Perpat } & \text { Permai } \\
\text { Association } & \end{array}$ \\
\hline Sources of Income & $\begin{array}{l}\text { Parking and } \\
\text { Food-Beverage } \\
\text { sales }\end{array}$ & $\begin{array}{ll}\text { Boat Rentals and } \\
\text { Boarding Rentals }\end{array}$ & $\begin{array}{l}\text { Voluntary Tickets, } \\
\text { Boarding Rentals, } \\
\text { Boat Rentals, Fish } \\
\text { food sales }\end{array}$ \\
\hline $\begin{array}{l}\text { Estimation amounted } \\
\text { to }\end{array}$ & $\begin{array}{l}800 \text { Thousand / } \\
\text { Month }\end{array}$ & 20 Million / Month & 2 Million / Month \\
\hline Allocation of income & 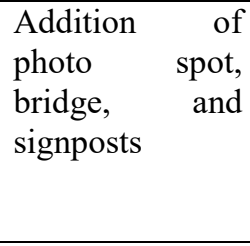 & $\begin{array}{l}\text { Honor manager, } \\
\text { operational, addition of } \\
\text { photo spot, pavilion, } \\
\text { and educational } \\
\text { activities, and Cash } \\
\text { Manager }\end{array}$ & $\begin{array}{l}\text { Addition of facilities } \\
\text { and implementation of } \\
\text { events }\end{array}$ \\
\hline
\end{tabular}

Therefore, from some of the data obtained it can be said that the principle of voluntarism is the initial principle which became the basis of thought. The results of field observation also showed that the managers were still struggling with the limited income from tourism services. The visits are not always crowded, while the incoming income is not balanced with the needs of development. This dilemma is a fundamental challenge because the need to get money as a result of tourism management is still limited, while regional development is also needed. In this condition, the principle of voluntarism is the key word because the actual economic impact is also still limited.

\subsection{Ecological commitment}

Based on the interview with managers, it is seen that the initial initiation of the communitybased environmental tourism movement is a commitment on the effort to save the environment. Economic orientation is not a motivation at first. Even it has reached the point where it has received quite a lot of visits, economic orientation is still a later consideration. As in the case of environmental tourism management in Kurau Barat Mangrove area, the income is divided into $60 \%$ for management and $40 \%$ for cash use. This cash is then re-mobilized for the need of regional development. 
Meanwhile, in the case of the management of environmental tourism area in Kolong Biru, the profit gained is more as profit over sales. Until now there is no charge to enter this tourism area. The managers take the profits from parking and food sales. Darwin, one of the managers even said that "to fulfill the daily meal is enough from selling", while for the development they rely on self-help sufficiently by using the profits from sales to set the shelter that needed by the visitors. Since this tourism area is supported by Karang Taruna and village government, they have received assistance in the form of asphalting roads and tourism awareness training for young people in this village. The commitment to support the effort to save the environment by encouraging ex-mining assets to become valuable tourism is the key word in this management, the motive for economic profit becomes the second consideration. Sarbani and Uziya, the residents interviewed said that local youths were enthusiastic to manage and beautify the area because they wanted to elevate their village's image by the existence of this environmental tourism. Even Roni Farizal, the village head said that because of the communication done with the youth then it was formed the Tourism Awareness Group in this area.

In the context of environmental tourism management in Rabeng Perpat Permai Belinyu, the commitment on the effort to save the environment is also a key issue. The profits are not maximized because a fixed rate has not been applied to enter this tourism area. The profits can be obtained from selling food and drink or from the orders of guest groups come. Tourism management is focused on maintaining mangrove and coastal areas supported by mangrove crab fisheries. From the profits of this cultivation they also get profits to manage the area more broadly in the form of developing the needs of visitors' comfort, such as boat, life jacket, and so on.

Buckley in his writing emphasized ecological commitment aspect as a part of ecotourism framework which includes conservation, sustainability, education, and nature-based tourism [11]. Based on his opinion, ecotourism is always connected with environmental issues, both directly and indirectly [see also $12,13,14,15]$. If we look at the data in this paper, then it can be said that ecological commitment is a sign that ecotourism is basically not just on the basis of natural tourism, but also on the spirit of salvation and protection.

In the context of community-based ecotourism management at this research locus, the pattern of ecological commitment is reflected in the following chart:

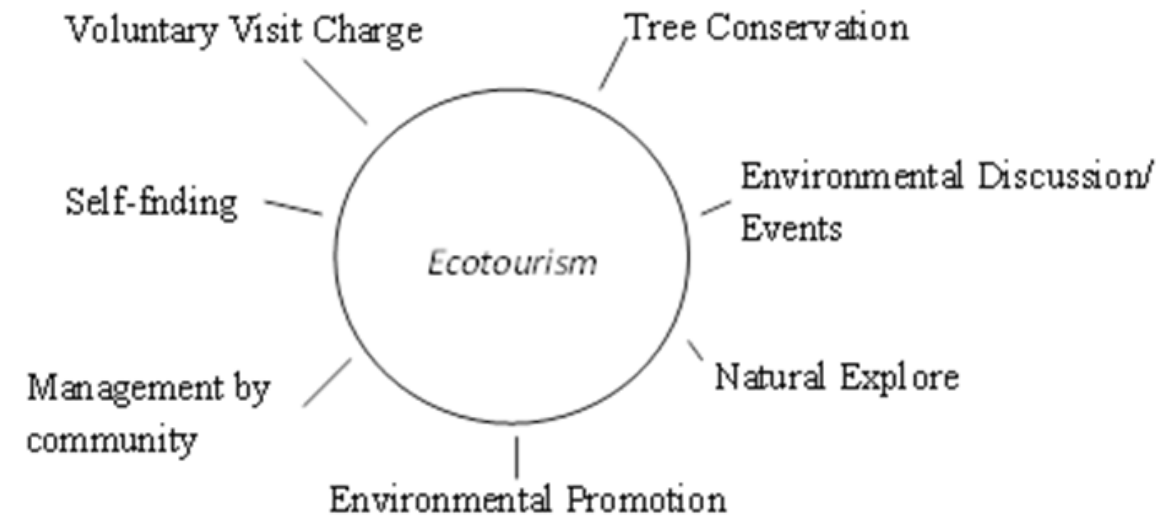

Figure 3. The Context of Ecological Commitment 
Based on the above scheme, it can be explained that the ecological commitment aspect is reflected in tourism in which not only enjoys the natural beauty given by the nature but is also movement oriented. Tree conservation is carried out in the form of tree planting, then held discussions and events related to the environment, tourism which is generally filled with natural explore, to the jargonization of environmental promotion aimed at inviting visitors to love the environment. While in terms of management, ecological commitment is reflected in the visit charge which is generally charged on a voluntary basis, the principle of self-funding at the funding level, especially at the beginning. The principle of community-based management also characterizes that ecotourism developed at this research locus is characterized by empowerment.

\subsection{Between Value and Business: Country Position?}

If all this time, the tourism management which is based on business and profit runs rapidly, in contrast to community-based environmental tourism management. Although the growth seems slow, but it cannot be denied that community-based management can in fact go hand in hand, at least, at the locus under this research. Currently, the popularity of nature tourism as a new tourism area on Bangka Island shows good development. The question is where is the country (read: government) position?

In the case of locus studied, the fact is that the country always comes later following the popularity of the development of community ideas. In the case of Kolong Biru for example, the government came precisely when there was a disagreement between whether Kolong Biru was in the position of Central Bangka Regency or South Bangka Regency. When the area was popular on social media and many tourists visited, the two governments even claimed each other as the owner. The fact is that the government will concern on the area when the area is gaining popularity and attracts many tourists.

The same thing happens in the case of the development of Kurau Barat Mangrove tourism area. After this spot began to be alternative tourism by the community, then the support arrives later, namely the license of management from the Forest Service. Although then the support came in swarms, but the basic initiation by the community became the main pillar of this tour. The community eventually became the main mover of this movement.

Meanwhile, in the management of Rabeng Perpat Permai environmental tourism, the initiation of the community to utilize available land came far earlier than the government support. The license for the use of the land itself was proposed and assisted after the area was visited by the Regional Head. The assistance from the regional government also followed later when the principle of self-help and self-funding had preceded it. Even today, the managers still relied on self-help funds for development. One resident who concerned on Rabeng named Sahwan Syarif, said that "So far, the local government has provided some support, but some are still self-funding, such as making mangrove tracking and small mosque"

Then the question is, is there something wrong with the late condition of government? At least there are some interesting things. First, the government certainly has an obligation to encourage the strengthening of community-based tourism management. The government can provide strong support in the form of financial assistance, facility assistance, and other relevant assistance, but is not intended as a way to then take over management from the community to be profit oriented by the local government. That is, there is a government obligation to encourage the implementation of the principle of communitarianism in the management of environmental tourism.

Second, the fact that the values accompany the process of using nature as environmental tourism should be a new orientation from the vision of ecological development. This value 
actually becomes as a social capital in the development of ecotourism [compare with 16]. Profitoriented tourism will be contrary to the principle of community and means to estrange the management principle from the environmental rescue movement. Because the basis is ecological commitment, the government should encourage the expansion of the idea of profitasization of the natural environment, besides hand it over to the private sector. In the end, the author considers that community-based environmental management is far wiser.

Third, from the above conditions, it seems that the local government has not yet focused on the development of community-oriented tourism which then becomes as community empowerment. It seems that the context of people's economy has not been built. The fact that the government support is still limited indicates that the local government has not been responsive on the strengthening of people's economy in the tourism sector. Of course, there is a need to encourage additional facilities with more adequate budgetary interventions in community-based ecotourism areas.

Fourth, encouraging the development of community-based tourism by placing nature as a new arena actually places the government's role in the right position among the interests of ecological protection, community empowerment, and strengthening the economic framework in the form of income. By supporting the community in the development of ecotourism, the government can utilize the potential that already exists in the nature, reduce development costs for tourism spots, and increase the economic income of the community.

The following is the scheme of relations between community, ecotourism, and country:

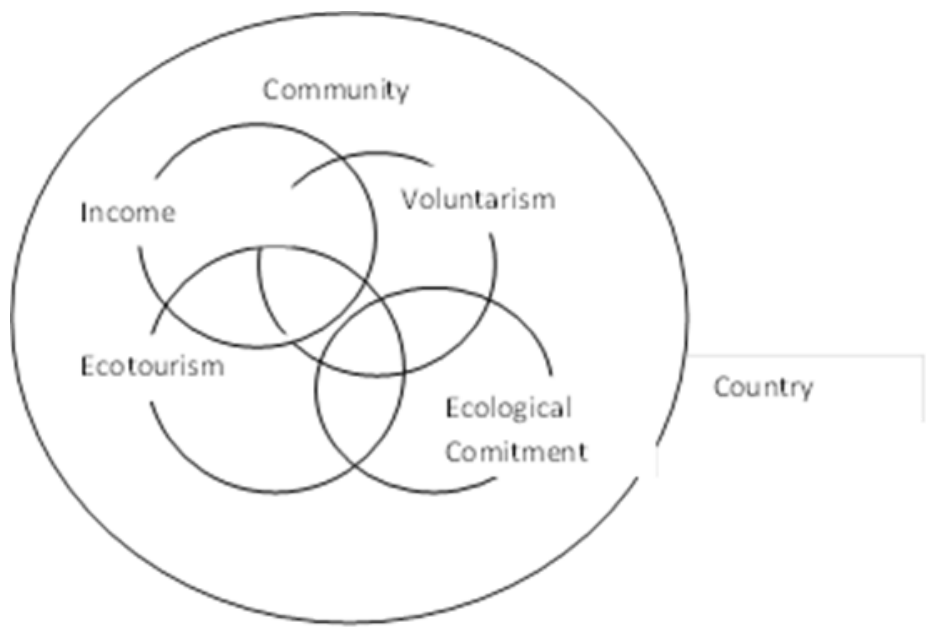

Scheme 1. The relationship between community, ecotourism, and country

The above scheme explains that in the development of ecotourism, the community deals with two main things, namely voluntarism as a condition where they do not pursue economic interests, ecological commitment becomes the basis of initiation, and the country which tend to arrive late. The above scheme at the same time shows that the community basically becomes the basic framework of thinking for the development of ecotourism at the research locus of this research. 


\section{Conclusion}

This study concludes that in managing community-based environmental tourism on Bangka Island, voluntarism is the dominant argument rather than economic interest. In this paper, it is explained that the managers face a dilemma between voluntarism and income, but they still persist because of a strong ecological commitment. In general, the managers are more focused on saving the environment rather than purely economic orientation, although they of course hope that profits can be one of the positive impacts from the management.

This study also found that in community-based environmental management, at least in the case of this research locus, the country in this case the government always came late. The support was certainly given, but initial initiation was born bottom up. Furthermore, in a framework which is more oriented to the interests of empowering and strengthening the community, in the future it is predicted that the government will prioritize community-based tourism management rather than those oriented to environmental privatization.

\subsection{Acknowledgements}

The author would like to deliver his thanks to the Directorate General of Higher Education, Ministry of Research and Technology that has given funds assistance in this research's activities under the scheme of Multi-Year Basic Research 2019-2021. The author also would like to deliver his thanks to his colleagues at FISIP Bangka Belitung University who have given a lot of support and input to improve the substance of this paper.

\section{References}

[1] P. S., "The Political Economy Dimension Towards Conflict of Mining Governance (Case Study: Bangka Belitung Governoor's Regulation About The Moratorium Of PT Timah, Tbk Offshore Tin Mining 2016),” J. Wacana Polit., vol. 3, no. 1, pp. 40-53, 2018.

[2] "Badan Pusat Statistik (BPS). Statisik Daerah Kepulauan Bangka Belitung. BPS Bangka Belitung (2018).".

[3] I. Ibrahim, D. Haryadi, and N. Wahyudin, "Already dependent: a dependency analysis of market activity on tin mining in Bangka Belitung," in E3S Web of Conferences, 2019, vol. 91, p. 3004.

[4] S. H. Hengky, "Beholding Tanjung Pesona coastal-ecotourism in Bangka Islands, Indonesia," Bus. Econ. Res., vol. 7, no. 2, pp. 102-117, 2017.

[5] I. Ibrahim, D. Haryadi, and N. Wahyudin, "Knowledge of the context, behavior, and expectations of miners in relation to the tin mining policies and practices in Bangka Belitung," Masyarakat, Kebud. dan Polit., vol. 31, no. 4, pp. 358-367, 2018.

[6] I. I., "Bangka Tin and The Collapse of The State Power," GSTF J. Law Soc. Sci., vol. 5, no. 1, pp. $1-7,2016$

[7] K. Hirotsune, "Tourism, sustainable tourism and ecotourism in developing countries," in Proceedings of the ANDA International Conference, Nagoya, Japan, 2011, pp. 5-7.

[8] S. Butarbutar. R, "Enviromental Effects f Ecotourism in Indonesia," J. Indones. Tour. Dev. Stud., vol. 1, no. 3, pp. 97-107, 2013.

[9] M. Wood, Ecotourism: Principles, practices and policies for sustainability. UNEP, 2002.

[10] G. Wall, "Is ecotourism sustainable?," Environ. Manage., vol. 21, no. 4, pp. 483-491, 1997.

[11] B. R., "A Framework for Ecotourism," Ann. Tour. Res. Vol. 21, No. 3, pp. 661-66, vol. 21, no. 3, pp. 661-66, 1994. 